\title{
FACTORS AFFECTING THE ACTUALIZATION OF FINANCIAL TECHNOLOGY PAYMENT SYSTEM
}

\author{
Astini Ni Made Dwi ${ }^{\star}$, Sukartha I Made, Suprasto Herculanus Bambang, Ariyanto Dodik \\ Faculty of Economics and Business, University of Udayana, Bali, Indonesia \\ ${ }^{\star} E$-mail: dwiastini.undhira@gmail.com
}

\begin{abstract}
The purpose of this study is to obtain empirical evidence regarding the factors that influence the actual use of fintech payments, especially among students on the island of Bali as the millennial generation. The type of data used in this study is primary data, which is collected through a questionnaire using an alternative 5 Likert scale. Respondents in this study were taken using the purposive sampling method. The data analysis technique in this study used the Partial Least Square (PLS) approach. The results of the analysis show that the perceived benefits felt by users of the fintech payment system, economic benefits, convenience, have a positive effect on actual use of the fintech system. Meanwhile, transaction speed has no effect on the actual use of the fintech payment system. The risks felt by users of the fintech payment system, financial risks, security risks, operational risks negatively affect the actual use of fintech payments.
\end{abstract}

\section{KEY WORDS}

Fintech payment, perceived benefits, perceived risk, actual use.

The combination of technology and financial system known as Financial Technology (Fintech) has developed rapidly in Indonesia. Among five types of fintech that are developing in Indonesia, fintech payment is the application that is most demanded by millennials as the largest market share. Payment transactions carried out online allow fintech payment users to make transactions easily and quickly. Even though fintech payments offer many benefits for their users, not a few users are skeptical of the use of fintech payments in the future because of the risks they may face. The actual use of fintech payments is influenced by various factors, both benefit factors and risk factors that can affect a person's intention to use the system.

Previous research on the factors that influence the actual use of fintech payment systems has yielded inconsistent findings. The inconsistency of the results of previous studies causes this study to combine various factors that influence the actual use of the fintech payment system. The purpose of this study is to obtain empirical evidence regarding the factors that influence the actual use of the fintech payment system. The theories that underlie this research are Theory Reasoned Action (TRA) and Theory Accepted Model (TAM). This study focuses on indicators of benefit factors and risk factors contained in a fintech payment application that can influence a person's intention to adopt a fintech payment system.

\section{HYPOTHESES}

Perceived benefits by fintech payment users have a positive effect on the actual use of fintech payments. In accordance with Theory of Reasoned Action (TRA) and Technology Acceptance Model (TAM), user perceptions of the usefulness and ease of use of a technology system will influence their decision to adopt the system. The results of research conducted by Abramova \& Böhme (2016), Uran (2015), Tingchi Liu, et al (2013), Meyliana, et al (2019), and Hermanto and Patmawati (2017), show that the perceived benefits of users have a positive effect. significant on the behavior of using a system. The higher the perception of the benefits of a fintech payment system, the greater the tendency to use the system. Based on these reasons, the hypothesis that can be developed in this study is: 
$\mathrm{H}_{1}$ : Perceptions of benefits felt by fintech payment users have a positive effect on the actual use of fintech payments.

The perceived risk of fintech payment users has a negative effect on the actual use of fintech payments. A person's negative assessment of the use of technology systems will affect user behavior in adopting the technology. In accordance with Theory of Reasoned Action (TRA) and Technology Acceptance Model (TAM), a person's intention to use a system is influenced by his perception of the ease of use and usefulness of the system. The level of risk perceived by users will reduce the intention to adopt a fintech payment system. The results of research conducted by Ryu (2018), Abramova \& Böhme (2016), Park, et al (2019), and Suyanto and Kurniawan (2019), state that the risk perceived by consumers has a negative impact on the use of a technology system. The higher the level of risk felt by users of the fintech payment system, the lower the actual use of the fintech payment system will be. Based on these reasons, the hypothesis that can be developed in this study is.

$\mathrm{H}_{2}$ : The perceived risk of fintech payment users has a negative effect on the actual use of fintech payments.

Economic benefits have a positive effect on the actual use of fintech payments. According to Ryu (2018), the economic benefits that can be enjoyed by fintech payment users are related to reducing costs and financial benefits from fintech transactions. The economic benefits felt by users of the fintech payment system can increase user confidence that the system is financially profitable so that it can increase the use of the fintech payment system. Research conducted by Ryu (2018), Nikita (2015), Park, et al (2019), and Pei, et al (2015) found that economic benefits have a positive effect on the use of a system. The higher the economic benefits of a fintech payment system, the higher the tendency to use the system. Based on these reasons, the hypothesis that can be developed in this study is.

$\mathrm{H}_{3}$ : The economic benefits have a positive effect on the actual use of fintech payments.

Transaction speed has a positive effect on the actual use of fintech payments. According to Gao et al., (2015), transaction speed can save time for fintech payment service users because of the cashless transactions offered by this application. In accordance with Theory of Reasoned Action (TRA) and Technology Acceptance Model (TAM), the transaction speed offered by the system can convince users that the fintech payment system is beneficial for its users, especially for saving transaction time. The results of research conducted by Gao et al., (2015) state that transaction speed has a positive effect on the intention to use a system. The faster transactions that can be made in the fintech payment system, the higher the tendency to use the system. Based on these thoughts, the hypotheses that can be developed in this study are as follows.

$\mathrm{H}_{4}$ : Transaction speed has a positive effect on the actual use of fintech payments.

Convenience has a positive effect on the actual use of fintech payments. According to Ryu (2018), convenience in transactions using fintech payments is associated with the portability and accessibility that users get when making transactions. The convenience that users feel when transacting with a fintech payment system can increase their intention and confidence in using the system. The results of research conducted by Ryu (2018) and Nikita (2015), show that user comfort has a positive effect on the use of a technology system. The higher the level of comfort felt by users of the fintech payment system, the higher the tendency to use the system. Based on these thoughts, the hypothesis that can be developed in this study is as follows.

$\mathrm{H}_{5}$ : Convenience has a positive effect on the actual use of fintech payments.

Financial risk negatively affects the actual use of fintech payments. Ryu (2018) states that financial risk refers to the potential financial losses that may occur when using fintech. The possibility of financial loss that occurs when transacting using fintech payments can reduce the intention to use the system. Research conducted by Ryu (2018), Abramova and Böhme (2016), found that financial risk has a negative effect on the use of a system. The higher the financial risk of the fintech payment system, the lower the actual use of fintech payments in users' daily transactions. Based on these thoughts, the hypotheses that can be developed in this study are as follows.

$\mathrm{H}_{6}$ : Financial risk negatively affects the actual use of fintech payments. 
Security risks negatively affect the actual use of fintech payments. Security risk in fintech payments refers to potential losses due to fraud or hacking that interfere with the security of intech transactions (Ryu, 2018). The negative perceptions of fintech payment users regarding customer data security can reduce their intention to use the system. The results of research conducted by Ryu (2018) and Park, et al (2019), state that security risk has a negative effect on the use of a system. The higher the security risk of a fintech payment system, the lower the tendency to use the system. Based on these thoughts, the hypotheses that can be developed in this study are as follows.

$\mathrm{H}_{7}$ : Security risks negatively affect the actual use of fintech payments.

Operational risk has a negative effect on the actual use of fintech payments. Operational risk refers to system vulnerabilities and changes in transactions (Abramova and Böhme, 2016). The negative belief of fintech payment users regarding the operational risks of the fintech payment management company can reduce the intention to use the system. The results of research conducted by Abramova \& Böhme (2016), Ryu (2018), found that operational risk has a negative effect on the use of a system. The higher the operational risk of the fintech payment system, the lower the tendency to use the system. Based on these thoughts, the hypotheses that can be developed in this study are as follows.

$\mathrm{H}_{8}$ : Operational risk has a negative effect on the actual use of fintech payments.

\section{METHODS OF RESEARCH}

This research was conducted on the island of Bali, especially for students studying at a university on the island of Bali. The data used in this study is primary data, which was collected through a questionnaire. Respondents in this study were taken using purposive sampling method. The number of respondents used in this study was 400 respondents. Testing of research instruments was carried out by testing the validity and reliability testing. The data analysis technique in this study used the Partial Least Square (PLS) approach.

\section{RESULTS AND DISCUSSION}

Table 1 - Instrument Validity Test Results

\begin{tabular}{|c|c|c|c|c|}
\hline No & Variable & Indicators & $\begin{array}{c}\text { Corr. } \\
\text { Coefficient }\end{array}$ & Info \\
\hline \multirow[t]{4}{*}{1} & Perceived Benefit (X1) & X 1.1 & 0,963 & Valid \\
\hline & & X 1.2 & 0,965 & Valid \\
\hline & & X 1.3 & 0,976 & Valid \\
\hline & & X 1.4 & 0,973 & Valid \\
\hline \multirow[t]{3}{*}{2} & Perceived Risk (X2) & X 2.1 & 0,964 & Valid \\
\hline & & $X 2.2$ & 0,949 & Valid \\
\hline & & $\times 2.3$ & 0,934 & Valid \\
\hline \multirow[t]{3}{*}{3} & Economic Benefit (X3) & X 3.1 & 0,970 & Valid \\
\hline & & $\times 3.2$ & 0,942 & Valid \\
\hline & & $\times 3.3$ & 0,961 & Valid \\
\hline \multirow[t]{3}{*}{4} & Transaction Speed (X4) & $\mathrm{X} 4.1$ & 0,968 & Valid \\
\hline & & $X 4.2$ & 0,968 & Valid \\
\hline & & $\mathrm{X} 4.3$ & 0,980 & Valid \\
\hline \multirow[t]{3}{*}{5} & Convenience (X 5) & X 5.1 & 0,976 & Valid \\
\hline & & $X 5.2$ & 0,984 & Valid \\
\hline & & $\times 5.3$ & 0,981 & Valid \\
\hline \multirow[t]{3}{*}{6} & Financial Risk (X 6) & X 6.1 & 0,968 & Valid \\
\hline & & X 6.2 & 0,966 & Valid \\
\hline & & X 6.3 & 0,942 & Valid \\
\hline \multirow[t]{3}{*}{7} & Safety Risk (X 7) & X 7.1 & 0,975 & Valid \\
\hline & & X 7.2 & 0,964 & Valid \\
\hline & & X 7.3 & 0,969 & Valid \\
\hline \multirow[t]{3}{*}{8} & Operational Risk (X 8) & X 8.1 & 0,985 & Valid \\
\hline & & $X 8.2$ & 0,969 & Valid \\
\hline & & X 8.3 & 0,980 & Valid \\
\hline \multirow[t]{3}{*}{9} & Atual Fintech Payment & Y 1 & 0,936 & Valid \\
\hline & (Y) Usage & Y 2 & 0,969 & Valid \\
\hline & & Y 3 & 0,970 & Valid \\
\hline
\end{tabular}

Source: Data processed, 2020. 
Based on the results of the validity test in Table 1, it can be concluded that all research instruments are valid, due to the correlation between each statement with a total score above 0.30 .

Table 2 - Reliability Test Results

\begin{tabular}{llll}
\hline 1 & Perceived Benefit (X1) & 0,978 & Reliabel \\
\hline 2 & Perceived Risk (X2) & 0,945 & Reliabel \\
\hline 3 & Economic Risk (X3) & 0,955 & Reliabel \\
\hline 4 & Transaction Speed (X4) & 0,971 & Reliabel \\
\hline 5 & Convenience (X 5) & 0,980 & Reliabel \\
\hline 6 & Financial Risk (X 6) & 0,956 & Reliabel \\
\hline 7 & Safety Risk (X 7) & 0,968 & Reliabel \\
\hline 8 & Operational Risk (X 8) & 0,977 & Reliabel \\
\hline 9 & Actual Fintech Payment Usage(Y) & 0,955 & Reliabel \\
\hline
\end{tabular}

Source: Data processed, 2020.

The results of the reliability test shown in table 2 shows that all research instruments are said to be reliable, where all instruments are suitable for collecting data.

Table 3 - R-Square Value (R2) of Endogenous Variables

\begin{tabular}{lll}
\hline & R- square & R- Square - Adjusted \\
\hline$P F P$ & 0,913 & 0,912 \\
\hline
\end{tabular}

Source: Data processed, 2020.

Based on Table 3, it can be seen that the value of the Adjusted $R$ Square is 0.912 which means that 91.2 percent of the variation in the actual use of the fintech payment system in this study can be explained by the variables of perceived benefits, perceived risks, economic benefits, transaction speed, convenience. , financial risk, security risk and operational risk. While the remaining 8.8 percent is influenced by other variables outside of the model used in this study.

Table 4 - Convergent Validity Test Results

\begin{tabular}{clc}
\hline No & \multicolumn{1}{c}{ Variabel } & $\begin{array}{c}\text { Average Variance } \\
\text { Extracted (AVE) }\end{array}$ \\
\hline 1 & Perceived Benefit (X1) & 0,913 \\
\hline 2 & Perceived Risk (X2) & 0,882 \\
\hline 3 & Economic Risk (X3) & 0,899 \\
\hline 4 & Transaction Speed (X4) & 0,927 \\
\hline 5 & Convenience (X 5) & 0,933 \\
\hline 6 & Financial Risk (X 6) & 0,920 \\
\hline 7 & Safety Risk (X 7) & 0,919 \\
\hline 8 & Operational Risk (X 8) & 0,929 \\
\hline 9 & Actual Fintech Payment Usage(Y) & 0,912 \\
\hline
\end{tabular}

Source: Data processed, 2020.

Based on the convergent validity test presented in table 4 , it shows that all variables have an AVE value greater than 0.5. This means that the average construct can explain more than half of the variance of the indicator.

Based on the discriminant validity test presented in table 5, it shows that the cross loading value of the related construct is greater than all the cross loading values of other constructs. This means that each construct is unique and describes a phenomenon that is not represented by other constructs in the model.

Based on the composite reliability test presented in table 6 , it shows that the values of composite reliability and Cronbach's alpha value are above 0.7 . This means that each construct is unique and describes a phenomenon that is not represented by other constructs in the model. 
Table 5 - Discriminant Validity Test Results

\begin{tabular}{|c|c|c|c|c|c|c|c|c|c|c|}
\hline No & Variabel & KT & KYM & MD & ME & PFP & RD & RKEA & RKEU & ROPR \\
\hline 1 & KT & 0,963 & & & & & & & & \\
\hline 2 & KYM & 0,886 & 0,966 & & & & & & & \\
\hline 3 & MD & 0,885 & 0,885 & 0,955 & & & & & & \\
\hline 4 & ME & 0,868 & 0,869 & 0,874 & 0,948 & & & & & \\
\hline 5 & PFP & 0,889 & 0,894 & 0,901 & 0,904 & 0,955 & & & & \\
\hline 6 & RD & $-0,858$ & $-0,853$ & $-0,856$ & $-0,876$ & $\mid-0,909$ & 0,939 & & & \\
\hline 7 & RKEA & $-0,857$ & $-0,858$ & $-0,861$ & \begin{tabular}{|l|}
$-0,862$ \\
\end{tabular} & $-0,897$ & 0,880 & 0,958 & & \\
\hline 8 & RKEU & $-0,842$ & $-0,852$ & $-0,847$ & $-0,858$ & \begin{tabular}{|l|l|}
$-0,894$ \\
\end{tabular} & 0,888 & 0,887 & 0,959 & \\
\hline 9 & ROPR & $-0,851$ & $-0,853$ & $-0,856$ & $\mid-0,861$ & $-0,889$ & 0,872 & 0,878 & 0,878 & 0,964 \\
\hline
\end{tabular}

Source: Data processed, 2020.

Table 6 - Composite Reliability Test Result

\begin{tabular}{|c|c|c|c|}
\hline No & Variabel & $\begin{array}{c}\text { Composite } \\
\text { reability }\end{array}$ & $\begin{array}{c}\text { Cronbach's } \\
\text { Alpha }\end{array}$ \\
\hline 1 & Perceived Benefit (X1) & 0,977 & 0,968 \\
\hline 2 & Perceived Risk (X2) & 0,957 & 0,933 \\
\hline 3 & Economic Risk (X3) & 0,964 & 0,944 \\
\hline 4 & Transaction Speed (X4) & 0,974 & 0,960 \\
\hline 5 & Convenience (X 5) & 0,977 & 0,964 \\
\hline 6 & Financial Risk (X 6) & 0,972 & 0,957 \\
\hline 7 & Safety Risk (X 7) & 0,971 & 0,956 \\
\hline 8 & Operational Risk (X 8) & 0,975 & 0,962 \\
\hline 9 & Actual Fintech Payment Usage $(Y)$ & 0,969 & 0,952 \\
\hline
\end{tabular}

Source: Data processed, 2020.

Table 7 - Path Value and Hypothesis Test

\begin{tabular}{|c|l|r|r|}
\hline No & $\begin{array}{c}\text { Hubungan antar } \\
\text { Variabel }\end{array}$ & \multicolumn{1}{c|}{ Path } & \multicolumn{1}{c|}{ P- Value } \\
\hline 1 & MD -> PFP & 0.164 & 0.001 \\
\hline 2 & ME -> PFP & 0.163 & 0.016 \\
\hline 3 & KT -> PFP & 0.075 & 0.074 \\
\hline 4 & KYM -> PFP & 0.112 & 0.016 \\
\hline 5 & RD -> PFP & -0.202 & 0.000 \\
\hline 6 & RKEU -> PFP & -0.109 & 0.003 \\
\hline 7 & RKEA -> PFP & -0.111 & 0.026 \\
\hline 8 & ROPR -> PFP & -0.081 & 0.037 \\
\hline
\end{tabular}

Source: Data processed, 2020.

The results showed that the perceived benefits felt by users of the fintech payment system had a positive effect on the use of actual fintech payments. This means that when users of the fintech payment system experience various benefits and advantages of using the system, it will have the potential to increase the actual use of the fintech payment system. The perceived risk of users of the fintech payment system has a negative effect on the actual use of fintech payments. This indicates that when users perceive the level of risk in the fintech payment system to be high enough, the tendency to adopt the system will decrease. The economic benefits felt by users of the fintech payment system have a positive effect on the actual use of fintech payments. This indicates that when users of a fintech payment system believe that the system can provide economic benefits, the actual use of fintech payments will tend to increase. The transaction speed felt by users of the fintech payment system has no effect on the actual use of fintech payments. This indicates that the transaction speed offered by the fintech payment system does not affect the user's intention to adopt the system. This condition can be caused by the fintech payment system which requires an internet connection, while in some areas, the internet connection does not reach and the signal varies in each region. In addition, respondents in this study, especially students aged 19 to 27 , did not place too much importance on transaction speed when using 
the fintech payment system. The comfort felt by users of the fintech payment system had a positive effect on the actual use of fintech payments. The higher the level of comfort felt by users of the fintech payment system, the more likely it will be to use the system. The financial risk felt by users of the fintech payment system has a negative effect on the actual use of fintech payments. This indicates that when users of the fintech payment system experience financial losses when using the system, the actual use of fintech payments will decrease. Security risks felt by users of the fintech payment system have a negative effect on the actual use of fintech payments. High security risks can reduce the user's intention to transact using a fintech payment system because losses related to data security are not only limited to material losses, but also moral losses. The operational risk felt by users of the fintech payment system has a negative effect on the actual use of fintech payments. This indicates that when users of the fintech payment system feel that the management system of the fintech payment company is weak, the intention to use the service will decrease, so the actual use of fintech payments also decreases.

\section{CONCLUSION AND SUGGESTIONS}

This study found out that the perceived benefits, economic benefits, and convenience felt by users when transacting with the fintech payment system have a positive effect on the actual use of the fintech payment system. Transaction speed has no effect on the actual use of the fintech payment system. Perceptions of risk perceived by users of the fintech payment system, financial risk, security risk and operational risk have a negative effect on the actual use of the fintech payment system.

Based on the research results, some suggestions can be made for further research. The next researcher can use a measure of transaction speed with certainty, so that the results obtained are not biased in each region. Further research can be carried out with a wider scope of area, and respondents from various circles so that the results obtained are more accurate. Further researchers can add research objects from various industrial fields, with a wider scope.

\section{REFERENCES}

1. Abramova, S., \& Böhme, R. (2016). Perceived Benefit and Risk as Multidimensional Determinants of Bitcoin Use: A Quantitative Exploratory Study. Proceedings of the ThirtySeventh International Conference on Information Systems (ICIS 2016), (Zohar 2015), 120.

2. Ahmad Zaenudin - 28 Desember 2018. (2018). https://tirto.id/menyambut-kejutankejutan-dunia-fintech-2019-dcGH.

3. Ajzen, I., \& Fishbein, M. (1977). Attitude-behavior relations: A theoretical analysis and review of empirical research. Psychological Bulletin, Vol. 84, No. 5, p. 888.

4. Arner, D., Barberis, J., \& Ross Buckley. (2016). The Evolution Of Fintech: A New PostCrisis Paradigm?

5. Asosiasi Penyelenggara Jasa Internet lindonesia. (2017). Penetrasi \& Perilaku Pengguna Internet Indonesia 2017. Penetrasi Dan Perilaku Pengguna Internet Indonesia, 1-39.

6. Barakat, A., \& Hussainey, K. (2013). Bank governance, regulation, supervision, and risk reporting: Evidence from operational risk disclosures in European banks. International Review of Financial Analysis, 30, 254-273. https://doi.org/10.1016/j.irfa.2013.07.002

7. Benlian, A., \& Hess, T. (2011). Opportunities and risks of software-as-a-service: Findings from a survey of IT executives. Decision Support Systems, 52(1), 232-246. https://doi.org/10.1016/j.dss.2011.07.007

8. Burhanuddin, C. I., \& Abdi, M. N. (2019). Tingkat Pemahaman dan Minat Masyarakat dalam Penggunaan Fintech. Owner, 3(1), 21. https://doi.org/10.33395/owner.v3i1.79

9. Chishti, S. (2016). Banking Beyond Banks and Money, 55-68. https://doi.org/10.1007/978-3-319-42448-4

10. Cindy Mutia Annur. (2019). Asosiasi Fintech Berharap Menteri Baru Tak Menghambat 
Inovasi.

11. Davis, F.D. (1986). A Technology acceptance model for empirically testing new-end user information systems: Theory and Result. Sloan: Sloan School of Management, Massachusetss Institur of Technology (MIT).

12. Davis, Fred D, Bagozzi, R. P., \& Warshaw, P. R. (1992). Extrinsic and Intrinsic Motivation to Use Computers in the Workplace' fred d. Davis .

13. Eka, R. (2018). https://dailysocial.id. Retrieved June 12, 2019, from https://dailysocial.id/post/fintech-report-2018

14. Featherman, M. S., \& Pavlou, P. A. (2003). Predicting e-services adoption: a perceived risk facets perspective, 59, 451-474. https://doi.org/10.1016/S1071-5819(03)00111-3

15. Gao, X., Clark, G. D., \& Lindqvist, J. (n.d.). Of Two Minds, Multiple Addresses, and One History: Characterizing Opinions, Knowledge, and Perceptions of Bitcoin Across Groups arXiv : 1503 . 02377v1 [ cs . CY ] 9 Mar 2015, 1-21.

16. Garvey, K., Byran Zhang, Hung, D.-Y. C., Deborah, P. R., \& Prof. Kong Ying. (2017). Cultivating growth, (September).

17. Ghozali, I. (2008). Structural Equation Modeling, Method Alternatif dengan Partial Least Square. Semarang: Badan Penerbit Universitas Diponegoro.

18. Ghozali, I. (2016). Aplikasi Analisis Multivariete Dengan Program IBM SPSS 23 (Cetakan ke). Semarang: Badan Penerbit Universitas Diponegoro.

19. Gia-Shie Liu, \& Pham Tan Tai. (2016). A Study of Factors Affecting the Intention to Use Mobile Payment Services in Vietnam. Economics World, 4(6), 249-273. https://doi.org/10.17265/2328-7144/2016.06.001

20. Gunaasih, S. A. P. P. (n.d.). Sang Ayu Putu Piastini GunaasihOPINI: Candu dan Tantangan Less-cash Society.

21. Hermanto, S. B., \& Patmawati, P. (2017). Determinan Penggunaan Aktual Perangkat Lunak Akuntansi Pendekatan Technology Acceptance Model. Jurnal Akuntansi Dan Keuangan, 19(2), 67-81. https://doi.org/10.9744/jak.19.2.67-81

22. http://www.kemenperin.go.id. (2019). kemeperindo. Retrieved June 1, 2019, from http://www.kemenperin.go.id/artikel/18581/Tumbuh-10-Persen,-Generasi-Milineal-

Dongkrak-Industri-Digital

23. Https://www.bi.go.id/id. (2019). https://www.bi.go.id/id. Retrieved June 2, 2019, from https://www.bi.go.id/id/peraturan/sistem-pembayaran/Pages/PBI_191217.aspx

24. Https://www.bi.go.id. (n.d.). Bank Indonesia sistem pembyrn. Retrieved from https://www.bi.go.id/id/sistem-pembayaran/Contents/Default.aspx

25. Https://www.bps.go.id. (n.d.). BPS. Retrieved from https://www.bps.go.id

26. https://www.kemenpppa.go.id/. (n.d.). generasi milenial kemepa. Retrieved from https://www.kemenpppa.go.id/

27. Https://www.ojk.go.id/. (n.d.). ojk. Retrieved June 1, 2019, from https://www.ojk.go.id/id/kanal/iknb/data-dan-statistik/fintech/Pages/lkhtisar-KeuanganFintech-(Peer-To-Peer-lending)-Periode-Februari-2019.aspx

28. Https://www.ojk.go.id/. (2017). Kajian Perlindungan Konsumen Sektor Jasa Keuangan: Perlindungan Konsumen Pada Fintech.

29. Kim, D. J., Ferrin, D. L., \& Rao, H. R. (2008). A trust-based consumer decision-making model in electronic commerce: The role of trust, perceived risk, and their antecedents, 44, 544-564. https://doi.org/10.1016/j.dss.2007.07.001

30. Kulsum, U. (2017). https://keuangan.kontan.co.id/news/fintech-payment-masihmendominasi-di-2018. Retrieved from https://fintech.id/

31. Kuo Chuen, D. L., \& Teo, E. G. S. (2015). Emergence of Fintech and the Lasic Principles. Ssrn. https://doi.org/10.2139/ssrn.2668049

32. Lee, M. C. (2009). Factors influencing the adoption of internet banking: An integration of TAM and TPB with perceived risk and perceived benefit. Electronic Commerce Research and Applications, 8(3), 130-141. https://doi.org/10.1016/j.elerap.2008.11.006

33. Lee, T., \& Kim, H. (2015). An Exploratory Study on Fintech Industry in Korea: Crowdfunding Case, 58-64. https://doi.org/10.15242/iie.e0815045

34. Meyliana, Fernando, E., \& Surjandy. (2019). The Influence of Perceived Risk and Trust in 
Adoption of FinTech Services in Indonesia, 13(1), 31-37.

35. Nikita. (2015). The Impact of Attitude , Subjective Norm , Perceived Behavioral Control, Trust, Perceived Benefit and Perceived Risk toward KlikBCA Usage Intention in Surabaya. IBuss Management, 3(2), 295-303.

36. Okazaki, S., \& Mendez, F. (2013). Exploring convenience in mobile commerce: Moderating effects of gender. Computers in Human Behavior, 29(3), 1234-1242. https://doi.org/10.1016/j.chb.2012.10.019

37. Panggalih, R. G., \& Baridwan, Z. (2016). Minat individu terhadap penggunaan internet banking: pendekatan modified theory of planned behavior. Jurnal IImiah Mahasiswa Fakultas Ekonomi Dan Bisnis Universitas Brawijaya, 1(2).

38. Park, J., Amendah, E., Lee, Y., \& Hyun, H. (2019). M-payment service: Interplay of perceived risk, benefit, and trust in service adoption. Human Factors and Ergonomics In Manufacturing, 29(1), 31-43. https://doi.org/10.1002/hfm.20750

39. Pei, Y., Wang, S., Fan, J., \& Zhang, M. (2015). An empirical study on the impact of perceived benefit, risk and trust on E-payment adoption: Comparing quick pay and union pay in China. Proceedings - 2015 7th International Conference on Intelligent HumanMachine Systems and Cybernetics, IHMSC 2015, 2, 198-202. https://doi.org/10.1109//HMSC.2015.148

40. Peter, J. P., \& Tarpey, L. X. (1975). A Comparative Analysis of Three Consumer Decision Strategies, 2(June), 29-37.

41. Pusat Data dan Informasi IImu Pengetahuan, Teknologi, dan P. T., \& Kementerian Riset, Teknologi, dan P. T. (2018). Statistik Pendidikan Tinggi. https://doi.org/10.1002/chem.200802548

42. Rahmatillah, intan novirani. (2017). Analisis Pengaruh Perilaku Penggunaan Teknologi Fintech Pada Ganerasi Milenial Di Kota Bandung. Buletin Ekonomi Moneter Dan Perbankan, 2(4), 68-122. https://doi.org/10.21098/bemp.v2i4.282

43. Ryu, H.-S. (2018). Understanding Benefit and Risk Framework of Fintech Adoption: Comparison of Early Adopters and Late Adopters. Proceedings of the 51st Hawaii International Conference on System Sciences, 3864-3873. https://doi.org/10.24251/hicss.2018.486

44. Ryu, H. (2017). Industrial Management \& Data Systems Article information: What makes users willing or hesitant to use Fintech ?: The moderating effect of user type. Industrial Management \& Data Systems, 118(3), 541-569.

45. Sindi, M. R. (2018). Pengaruh penggunaan uang elektronik (e-money) bank mandiri terhadap kemudahan transaksi masyarakat di kabupaten ponorogo.Http://Eprints.Umpo.Ac.Id/4042/.

46. Sugiyono. (2014). Metode Penelitian Pendidikan Pendekatan Kuantitatif, Kualitatif, dan R\&D. Bandung: Alfabeta.

47. Suyanto, \& Kurniawan, T. A. (2019). Faktor yang Mempengaruhi Tingkat Kepercayaan Penggunaan FinTech pada UMKM Dengan Menggunakan Technology Acceptance Model ( TAM ), 16(1).

48. Tingchi Liu, M., Brock, J. L., Cheng Shi, G., Chu, R., \& Tseng, T. H. (2013). Perceived benefits, perceived risk, and trust: Influences on consumers' group buying behaviour. Asia Pacific Journal of Marketing and Logistics, 25(2), 225-248. https://doi.org/10.1108/13555851311314031

49. URAN, R. (2015). Implementasi technology acceptance model pada penerimaan dan penggunaan media sosial path.Http://E-Journal.Uajy.Ac.Id/6888/.

50. Wilkie, L., \& Pessemier, A. (1973). Marketing 's Use Attitude Models, 10(4), 428-441.

51. Woetzel, J., Seong, J., Leung, N., Ngai, J., Manyika, J., Madgavkar, A., ... Mironenko, A. (2019). https://www.mckinsey.com. Retrieved June 1, 2019, from https://www.google.com/search?q=google+translate\&rlz=1C1CHBF_enID807ID807\&oq= google+tras\%3Bat\&aqs=chrome.1.69i57j015.4714j1j7\&sourceid=chrome\&ie=UTF-8

52. www.finansialku.com. (2018). Apa itu FinTech Indonesia? Retrieved July 15, 2019, from https://www.finansialku.com/apa-itu-industri-financial-technology-fintech-indonesia/

53. Zavolokina, L., Dolata, M., \& Schwabe, G. (2016). FinTech - What's in a Name? 